\title{
Mircea Eliade's Research Method in the Field of the History and Philosophy of Religion
}

\author{
Stelian Manolache \\ $\mathrm{PhD}$, Assist. Prof. University Ovidius, Constanta, Romania \\ stelian81stely@yahoo.com
}

\begin{abstract}
As a historian and philosopher of religions, a gifted narrator and talented essayist, with a fascinating work of articles, studies and research volumes (Eliade 1991, 93), Mircea Eliade must be discovered and decrypted in a religious key, leaving aside the confusion ethnic - aesthetic. Thus, Eliade affirms his own credo, writing that inside the same ethnical mass, the culture is produced not by the ethnic fibre, it is produced by a bouquet of nuclei developed spiritually, most of the time by religion (Eliade 1990, 40; David 2010,27) ... the mystic experience - the functional actualisation of the religious reality - being the only effective one (Eliade 1990, 52). In this context, his friend Petre Țuțea, wrote that Eliade must be thought/ understood inside the existential triangle God-human-nature, a triangle ruled by the category of the archetypal sacred and of the symbol (David 2010, 108), meaning the All-including Real, the unique cause of all things (T,uțea 2013, afterword).

His research approach on sacred and profane, also on the religious behaviour, is a complete method of the religious thinking (T, Tuțea 2013,15), establishing a dialogue between science and religion for the sake of the Absolute Truth. Occasioned by the celebration of 110 years from the birth of Mircea Eliade, we will discuss in our paper this method included in the dialogue between science and religion, its originality, translated not only with the access to the Significance of the Truth through Revelation (Țuțea 2013, 15), but also with the freedom of thinking and aspiring to the immortality of the soul.

KEY WORDS: homo religious, sacred, profane, Emile Durkheim, Wilhelm Schmidt, Sigmund Freud, Carl Gustav Jung, Georges Dumezil.
\end{abstract}




\section{Preliminaries}

The beginning of the $20^{\text {th }}$ century is characterised by the appearance of new historicalsocial-ethnological methodologic and phenomenological-psychological reductionist approaches in the research field of the sacred and the profane as well in the field of the behaviour of the religious man. From this perspective, the year 1912 is a turning point for the history and philosophy of religions, because, in an exceptional research coincidence, several works were publishes, while, during the second half of the century, they will be the premises for the development of a new research methodology for the religious phenomenon. The research published in 1912 starts with the appearance of The elementary forms of the religious life, written by the sociologist Emile Durkheim.

In his opinion, the sociologist must offer privilege to the religious phenomena, because religion contains from its origins the elements that will give birth, through transfiguration, to various manifestations of the collective social life, as science, art, poetry and morality. For Durkheim, religion is an integrative social phenomenon, a natural manifestation of the human activity, an emanation of the collective consciousness, a universal and eternal objective cause of the religious experiments inside the society, also an a priori absoluteness aiming to manage the Sacred. In his research, the key concept is the notion of collective consciousness, meaning the sum of beliefs and feelings common to the members of the society.

This collective consciousness, transcending the individual consciousness, is present in religion and may be seen as a natural manifestation of the human activity, while the society is a superior metaphysical reality transcending the individual. A step further is taken by the priest Wilhelm Schmidt, author of The origin of the idea of God, bringing another method for the research on the origin and the life of religion, this time from a Christian perspective, an ethnological-historical-cultural perspective, highlighting the thesis of the primordial monotheism, the ancestral and universal character of the religion/religiosity based on the relation with a unique mighty Supreme Being. Also in 1912, Sigmund Freud finishes his work called Totem and taboo, starting his research on the origin and the being of religion from the idea of parricide of the father by the son. Another researcher, Carl Gustav Jung, publishes Transformations and symbols of the libido, also promoting the research of the human subconscious from the perspective of the psychoanalysis.

Raffaele Pettazzoni and his work Primitive religion in Sardinia configure a new perspective on the approach of the history of religions, by integrating the strong points of the previous scientific methodologies, and highlighting the historicity of each particular analysed religious phenomenon, revealing the complementary importance of the sociological, ethnological and psychological approaches - all offering the necessary and opportune 
contextualization for a more adequate understanding of homo religiosus and the judicious understanding of his behaviour. Raffaelo Petazzoni shows that, for reaching a maximum of cognitive efficacy, the research of the religious phenomena must be performed according to the historical method, without minimising the contribution of new domains as archaeology, philological analysis, the critique off the written and oral traditions or the integrated analysis of the myths/mythologies and of the rituals, whose specialised contribution cannot be ignored.

A step further is made by Georges Dumezil, who considers that the research on the nature and the functions of the sacred, on finding the origin of the religions and on decoding the religious behaviours must be based on a double knowledge, a knowledge of the religious phenomena combined imperatively with a knowledge on the circumscribed institutional contexts.

Applying this working method with comparative historical and philological elements, Georges Dumezil intended to obtain an exact cognitive image of a prehistorical determined religious system, which generated directly or indirectly the religious systems historically accredited. He is interested mostly not in the religious ethnology and sociology, but in the effective architectural structure of the religious systems, and their functional infrastructure and mechanisms.

Based on these observations, after 50 years of research, the French researcher will publish his monumental work Myth and Epic (Dumezil 1993), where, analysing a series of particular socio-religious systems and highlighting their convergent elements, Georges Dumezil concludes on the existence of some well-determined tripartite hierarchical structure of a doctrine ideological and ritual-cultic content of each religious phenomenon. This tripartite structure includes:

1. the magical and juridical power coming from the power of the god who establishes and justifies the divine law;

2. the physical force, used inclusively in the armed conflicts;

3. the fecundity, dutiful to the first two, but indispensable for their development.

These marks, specific to the archaic Indo-European populations may be found in time also in the western Christian world, in spite of the long historical metamorphosis. Here, between the $9^{\text {th }}$ and the $13^{\text {th }}$ century, the tripartite structure is highlighted in the poem written by Adalberon of Loan for Robert the Pious, a poem that presents the triad composed of oratores, bellatores and laboratores, a continuation of the old Hindu social categories: 1 ) the caste of the nobles and priests, 2) the caste of the warriors and 3) paria. 


\section{The fundaments of Eliade's thinking}

Born in 1907 in Bucharest, Mircea Eliade spends his childhood in various towns with military basis, as Râmnicu Sărat or Cernavodă, where his father a military professional works by contract; he returns in Bucharest in 1914 (T, urcanu 2007). After finishing the primary school, he is admitted by the College Spiru Haret, where he is drawn by the study of natural sciences and chemistry. He starts during this period to publish a lot of articles, reaching a number of 100 articles in 1925 (Eliade 1991, 105). After obtaining the baccalaureate degree, he attends the Faculty for Philosophy, where he is amazed by the courses of the professor Nae Ionescu. His publishing activity continues in 1926 with the establishment of "Revista Universitară" and the cooperation to "Cuvântul", where he starts to come closer to religion, especially to Orthodoxy. Similar to the ideas of Nae Ionescu, Eliade writes that: the orthodoxy is for us the authentic Christianity (Eliade 1990, 52). We, the young generation, will be - no matter how late - Orthodox Christians. There will be present all those that previously have tasted the metaphysical meaning of life (Eliade 1990, 59). It is the period when he is drawn to the research of the History of Religions, through the works of some important names in the field as Raffaele Pettazzoni, Max Muller and Edward Tylor. Eliade is not much interested in the philological analysis of the religious texts of Max Muller, and in the evolutionist anthropology of Edward Tylor, but more in the ideas of Pettazzoni, who proposed the overcoming of the reductionist intellectual dualism by emphasizing the historical reflections (T, urcanu 2007, 92), by researching the compared religions and by finding new research methods in the field of History and Philosophy of Religions. It is the time when, reading the works of Rudolf Otto, Tucci and Rene Guenon, Eliade begins to be interested in studying the universal character of the religions, generating his travel to India in 1928.

For three years, in Calcutta, he studies with a grant the Indian spirituality under the guidance of the eminent professor Dasgupta. He returns to Romania in 1933 and begins to teach at the University of Bucharest and to research religions, an activity confirmed in 1936 by the $\mathrm{PhD}$ thesis called Yoga, an essay on the origins of the Indian mysticism. With precursor as Emile Durkheim, from whom he uses the syntagma of sacred-profane; Rudolf Otto - highlighting the nature and the function of the sacred/das ganz andereand the contribution of the religious man to the act of the religious knowing of numen and of the phenomenology - in three stages of mirror, tremendum, fascinans - explaining the experiences through their connections; Gerard Van der Leeuw - from whom he uses the explanation of the inner structures of the religious phenomena, the religion and its two facets - the mystery and the lived experience; and Raffaele Pettazzoni - for a more adequate understanding of homo religiosus and the judicious aspect of the behaviour from 
a historical perspective, Mircea Eliade brings his own methodological orientation, a new and profound one, in the field of the history and philosophy of religions.

Due to his multicultural opening, he is appointed in 1940 as cultural counsellor to the Romanian Embassy in London and later in Lisbon. After the end of the World War II, he remains in Paris and later in Chicago, where he spends the last part of his life, until his death in 1984. Similar to his friend Georges Dumezil, Mircea Eliade will observe the essential role of the researcher - historian of religions must give to the structures and the mechanisms of the religious thinking in generating ideal/doctrine contents of the beliefs, as well as interdependence relations created between the religious myths and rite/rituals.

Mircea Eliade will be interested in the binomial religious man vs. natural ma, the first category adopting a specific behaviour related to a transcendent factor called sacred, to which it relate and according to which it creates, based on faith, a certain religious life. From this perspective, in the Treatise of History of Religions (1949), the Romanian researcher will aim to impose new research directions/methods for the history of religions, religious myths and symbols, sacred and homo religiosus. After researching the Indian religions and the beliefs of the peoples with no system of writing and after the meeting and the discussion with Gustav Jungon the problem of the religious archetypes and symbols, during the famous conferences from Eranos/Switzerland, Mircea Eliade will draw some fundamental conclusions:

1. the religious man tends to return periodically to the archetypal pattern, understood as example, paradigmatic model (Eliade 1946, 140),

2. these archetypes are placed on three levels: conscious, subconscious and transconscious;

3. by appealing to the symbol, the archetype takes various forms/morphologies. In the subconscious, it takes the form of dreams, hallucinations and reveries, and in the trans-conscious it takes the form of esthetical, ritualist or mythological visions; all these archetypes are to be found in the structure of the human conscious as a given and not as a historical-cultural acquisition of the time;

4. when the religious phenomenon reaches a critical level of intensity, the religious images and symbols - treasured consciously or unconsciously by the man under the form of the archetypes - become manifested/transfigures in a quantifiable manner, so the religious phenomena will be nothing more than the infinite dense expressions of the religious experiences lived in illo tempore.

For Mircea Eliade, this will be the priory orientation that must be assumed by the historian of religions and the specialised research should aim first on religion and not 
on history (Eliade 1952, 36). This is a total hermeneutics/interpretations (Eliade 1971, 115) as called by Mircea Eliade, one that is destined to decode and explain any meeting/connection of the religious man with the sacred. It represents, in fact, a search for original/ primary meanings, so the researcher will have, according to Mircea Eliade, a triple complementary responsibility: historical, phenomenological and hermeneutical. We will discuss this triple responsibility as follows.

\section{The historical perspective}

For Mircea Eliade, the historical research represents the first component of his research method, because no historian of religions can renounce to the historical context; the religious phenomena manifests during history, in well determined historical contexts. Thus, the historical perspective is necessary to reconstruct the evolution in time and space of the religious forms, of the concrete manner in which the cultural and economic-social factors influenced and modelled them. The archaic religions, as well the primitive religions or those less or not at all conceptually established, require this analytical perspective, as well as the big religions of the world, because they cannot be separated from their historical context without the risk of diminishing the correctitude of the diagnosis. In fact, any religious phenomenon can be seen as a historical act, because, as Mircea Eliade writes, "we know very well that we deal with religious phenomena and, by the simple fact that they are phenomena, in other words that they discover themselves, reveal to us, they are like a medal embedded in time, for the historical moment that gave birth to them" (Eliade 1952, 39).

In the same time, the Romanian researcher shows that the historian of religion should not substitute the work of the specialists from other domains, being obliged to keep the pace with the progresses in all the fields connected to his interests: "Certainly, there is no pure religious phenomenon, because religion is something human, and, implicitly, is also social, linguistic and economic" (Eliade 1948, 11). The information from the connected research fields will be corroborated with the information specific to the history of religions and will lead to a richer possibility of decoding, understanding and explaining correctly and integrative the religious systems, divine characters or religious rituals.

\section{The phenomenological perspective}

If the religious phenomenon may be understood correctly only in social, economic, political and historical context, we must understand in the same time that "the historian 
of religions did not end his work by reconstituting the history of the religious forms or by extracting their social, economic and political content; he also must understand their significance" (Eliade 1971, 18-19). Thus, to be understood correctly, any religious phenomenon must be seen beyond its historical content and delimitations, in other words, it cannot be explained only using the means of the history and of the historiography, because they do not operate to a spiritual level. In his specific content, the relation with the sacred and the spiritual life step outside the area of a simple historical investigation. Eliade reproaches, in this context, to some researchers the fact that they reduced the history of religions to the desacralizing "isms" of the sociology, psychology or history, falling into sociologism, psychologism of historicism.

All these perspectives, for him, lost the essential fact that the religious acts are the sui generis experience of a meeting between the human and the sacred, an experience on three levels ${ }^{1 .}$ Thus, the Romanian researcher highlights the symbolical and spiritual force of the religious phenomenon, its inner coherence, taking from the work of Rudolf Otto-Das Heilige-the conclusions of the description and analysis of various manner of expressing the numinous, understood as fascinans, mirror, tremendum and sanctum. If Mircea Eliade understood from Rudolf Otto the important of the specific feature of the religious experience, relating to the work of Van der Leeuw, Eliade will extend his research of the religious phenomenology seen as a study of the infrastructure of the religiousness.

Although appreciating a lot the work of Vand der Leeuw, Mircea Eliade reproaches to him the he reduced the ensemble of the religious phenomena to only three elements of structure: dynamism, animism and deism. Eliade's progress in researching the religious phenomenology is to bring under an integrated vision the operationalisation of the systematic steps destined to decode exhaustively the religious acts/phenomena, correlated with profound diagnosis of the religious reality (Eliade 1971, 115). In parallel, Mircea Eliade is not satisfied only by analysing the historical manifestations of homo religiosus; he tries to understand deeper its significances.

The phenomenological approach put him in the situation to decode the religious acts in an attempt to transcend the temporality and to come into contact with a last reality; thus, the fundamental role of the historian of religions is to deduce and decode the historical and cultural contexts that made possible a certain religious act/phenomenon (Eliade 1962, 242). For this, Mircea Eliade uses an adequate terminology, that of kratophany/hierophany/epiphany - a quantifiable manifestation of the sacred - trying not only to reconstruct its manifestation - related to rite, myth, cult or god - but also to make possible/intelligible the manifestation of the sacred into the world ${ }^{2}$. 
This is the centre of Eliade's research method, because he assumes the mission of identifying the presence of the transcendent in the human experience, in what is more reducible and original in the construction of the man: before writing the history of one thing, it is necessary to understand well the thing in itself and for itself (Eliade 1952, 36).

The sacred as hierophany manifests as an objective reality, revealed from an order different from the natural one, an active entity making its presence known and showing to the human in many ways (Eliade 1948,24). The so-called das Ganz andere becomes recognisable: (a) in a multitude of veiled forms, from the symbolical practices of production to the productive types of works and the ritualist sacrifices and concrete wars or (b) in the mythical acts of various gods, the actualization of their acts becoming examples of survival the daily life of the believers (Eliade 1948, 15-16).

In conclusion, the sacred manifests as a reality belonging to a level different from the natural one, is never in a pure state, but it is and remains always the same; the sacred manifests in something, through something and with (next to) something, every time in a direct correspondence with the numinous world.

In other words, the kratophany/hierophany as a manifestation of the sacred covers inside the phenomenology the field of the subjectivity and the field of the objectivity in the same time. What is specific to these manifestations is their content structured on three levels:

1. the natural object - a "house" of the sacred

2. the invisible reality - the sacred per se and

3. the mediator object of the revelation (Ries 1978, 80).

While the natural object remains what it is, because the sacred stone remain as stone, and the sacred tree remain as tree, the invisible reality designates the opening to the transcendence, to the world of the gods, the third element, the mediator element, represent the central factor because, inside any element or common being, there is embodied all that is something else, the biggest mystery, the sacred as totality, but one that is self-limited and historicised.

\section{The hermeneutical perspective}

For Mircea Eliade, the merit of the phenomenological method resides in the identification and the morphologic and typological classification of the religious 
phenomena, but, beyond this major and incontestable results, it permits no progress for knowledge, because the fact that a myth or a ritual is always historically conditioned does not explain the appearance and the existence of that myth or ritual. In other words, the historicity of the religious experience cannot tell us what is it and its fundamental significance (Eliade 1971,107), as well as we may observe the sacred in its manifestations, without their study revealing us what the sacred is or the metaphysical essence of the religious experiences.

In this context, the role of the specialist in hermeneutics becomes decisive for a deeper knowledge in the field of the history of religions; while the role of the phenomenologist is to observe the absolute reality and highlight the presence of the mediator agent, the hermeneut has the difficult mission to deliver the content of the message revealed through the mediator agent.

For Mircea Eliade, this message is closely connected to the experience of discovering the sacred space a primary religious experience. The sacred space opens above, intermediated by the symbol, which connects the phenomenal world and the numinous world, the divine world are, on one hand, imago mundi, and, on the other hand, axis mundi, "uniting" the celestial with the earth. Mircea Eliade underlines that "... the appearance of the sacred not only projects a fix point in the amorphous middle of a profane space $[\ldots]$, but it also creature a level rupture, opening the communication between the cosmic levels and making possible the ontological passage from a way to another one" (Eliade 1971, 107).

In the heterogeneous profane space, the "level rupture" generates the centre/ axis of the world used for the communication with the transcendent. The role of the hermeneutics is to perform the exegesis of the religious acts, to compare and order them from the most significant perspective, explaining in the same time their revealed message and extracting the trans-historical content from the historical and phenomenological acts:

"I think that it is useful to repeat that homo religiosus represents the total man; thus, the science of the history of religions must become a total science [...]; it is not enough to observe the significance of a religious phenomenon from a given culture, because its message must be decoded, one that has a cipher as all the religious phenomena have" (Eliade 1971, 107).

In this context, Mircea Eliade insists on the capacity of the hermeneutics to put the man in contact with the spiritual world, a superior contact from the point of view of the metaphysical content: "in the end, the history of religions is a total hermeneutics 
called to decode and explain the meetings of the man with the sacred, from ancient times until our days" (Eliade 1971, 30-31). Due to the hermeneutics, the history of religions becomes rigorous and exact, beyond its strictly intuitive valences. For the risk of ignoring or vulgarizing the religious forms or their significances, the hermeneutics brings the solution of the possibility to decode religious meanings and messages, otherwise inaccessible, translating them into a common language and preserving their intrinsic value, without substituting "the history of religions to the religious experiences or to the experience of the faith" (Eliade 1971, 19\&124-125), because, highlighting the last mentioned, we could dilute or even compromise the significance and the scientific content of the science.

\section{Conclusions}

For Mircea Eliade, the history of religion is a total science; thus, it must be approached from a triple perspective: historical, phenomenological and hermeneutical. If the historical research places all the religious phenomena in a well delimited temporal frame from social, political, economic, etc. points of view, and extracts conclusions derived from this type of contextualization, the phenomenological perspective treats the religious phenomenon as a unique experience, through the type of experience created by the meeting between the human and the divine in a well delimited historical context and generates a certain behaviour for the one experiencing the contact with the divinity. Implicitly, the phenomenological vision will permit the scientific inventory of various religious behaviours, and, in the same time, their morphological and typological evaluation.

Based on the achieved accumulations, the hermeneut will interpret and order the religious phenomena and behaviours, decoding their trans-historical perennial message. The triple perspective approached by Mircea Eliade has as centre of its preoccupations the man with religious behaviours, bomo religiosus, who, through the natural revelation, intuits the reality of the sacred, of the divinity, even he is able to understand it only symbolical, incomplete and diffuse.

Thus, the man experiences the presence of the sacred as a mystery bursting from the transcendence and coming into contact with the immanence, because the most physiological acts - hunger, sexuality, survival in a world dominated by the terror of the history - can be put in symbolical connection with the divinity through the ritual. In fact, the man searches continuously to relate to the sacred, by any mean or method, seen as legitimate in the absence of the access to the supernatural revelation; understanding this aspect, the historian of religion has to decode the manner the 
man acts in the name of the divine face he was created after and whom he wears in any circumstance.

\section{Notes}

${ }^{1}$ The first level is the concrete historical one, where the religious act seem to be very complex and heterogenous; the second level is the psychic-mental one, specific to the private religious experience, relevant from a phenomenological and hermeneutical perspective; the third level is the level of the "spirit", where the sacred resides, its manifestations forming what is called in phenomenology a religious act or phenomenon. The first level permits us to investigate the religious phenomenon under the aspect of 1) the sacred itself; 2) the sacred acts and 3 ) hierophanies. The second level reveals the meanings of the religious experience lived as a manifestation of the sacred. Finally, the third level sends us to the ultimate, transcendent and incomprehensible, reality. Cf. Cristian Petru, Natura şi cunoaşterea faptului religios în religiologia fenomenologică, in ***, Rațiune şi credință, București, Editura Ştiințifică şi Enciclopedică, 1983 p. 243.

${ }^{2}$ Eliade, Traité de l'bistoire des réligions, p. 12; p. 19. Per se, the revelation of the sacred is a mysterious act, belonging to a reality which is not part of the natural world. Cf. Idem, Sacré et profan, translated by Brînduşa Prelipceanu, București, Humanitas, 1995, p. 15.

\section{References}

David, Dorin. 2010. De la Eliade la Culianu. Cluj Napoca: Eikon.

Dumezil, Georges. 1993. Mit şi epopee, trad. Francisca Bălticeanu, Gabriela Creția, Dan Slusanschi. Bucureşti: Ed. Ştiințifică.

Eliade, Mircea. 1948. Traitéd'histoire des religions. Paris: Payot.

Eliade, Mircea. 1952. Images et symboles. Paris: Gallimard.

Eliade, Mircea. 1962. Mephistophélès et l’androgyne. Paris: Gallimard.

Eliade, Mircea. 1971. Nostalgie des origines. Paris: Gallimard.

Eliade, Mircea. 1973. Fragment d'un journal. Paris: Gallimard.

Eliade, Mircea. 1990. Profetism românesc. Bucureşi: RozaVânturilor.

Petru, Cristian. 1983. Natura şi cunoaşterea faptului religios în religiologia fenomenologică. In vol. *** Rațiune şi credință, Bucureşti: Editura Ştiințifică şi Enciclopedică.

Ries, Julien. 1978. L'Expression du sacredans les grandes religions, Louvain-la-Neuve.

Țurcanu, Florin. 2007. Mircea Eliade. Prizonierul Istoriei. București: Humanitas.

Țuțea, Petre. 2013. Mircea Eliade. Cluj Napoca: Eikon. 